\title{
Colonial Ideology, Colonial Sciences and Colonial Sociology in Belgium
}

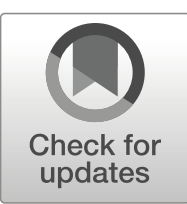

\author{
Marc Poncelet ${ }^{1}$
}

Published online: 9 June 2020

(C) The Author(s) 2020

\begin{abstract}
At the turn of the twentieth century, Belgian sociology and Belgian colonialism in Congo developed into a small political and academic elite that shared the same ideological stances. Colonialism played a more significant role. Colonization provided a new stage for emerging disciplines such as geography and sociology - which played their part in creating a brand new Belgo-African ethnology. Despite being a work in progress, sociology (which mainly involved jurists and lawyers) found a key place in the new institutional colonial sciences network. A colonial consensus was reached between Catholic and Liberal elites during the colonial crises and polemics that were also theoretical battles. Colonial sociology aspired to become the encyclopedic ethnology of the last African Terra incognita, as well as the government's modern science of the indigenous people. Missionaries, colonial magistrates and administrators carried out field research. It gradually generates a significant output on the scale of the social sciences of the time. But it was more closely linked to the institutions of colonial power than to academic institutions. As colonial sociology partially freed itself from the colonial context during the 1950s, under the banner of professional ethnology, on the one hand, and the sociology of development on the other, it had to contend with a dramatic decolonization process. Quite rightly considered colonial sociology but not sociology of colonization, its success can, however, not be summed up in a single ideology. Colonial sociology never was an effective instrument of domination or tool for liberation; it has never entirely succeeded in influencing the dominant institutions and ideologies. The discipline has a rather uneven and unstable timeline due to the physical and moral distance between the field and the Belgian metropolis.
\end{abstract}

Keywords Colonialism $\cdot$ Belgium $\cdot$ Sociology $\cdot$ Congo

Marc Poncelet

Marc.Poncelet@uliege.be

1 Social Sciences Faculty, University of Liège, Liège, Belgium 


\section{Looking Back. From “Development Studies" to Colonial Sciences}

Thirty years ago, I examined the scientific and academic foundations of the concept of development. In the second half of the twentieth century, it had established itself as the first global (universal) concept in the social sciences.

In the 1950s, the social sciences had, in fact, experienced a tremendous renaissance in Western Europe, both in the academic community and in the world of public policy. However, having kept a low profile during the interwar period, sociology appeared set to become the linchpin of a new social and political paradigm. The concept of development had emerged out of this European ferment.

At the same time, in the colonies, the notion of development was used by colonial reformers and indigenous elites to create a "colonization of development" to take over from the "mise en valeur" (economic exploitation of resources) on the one hand and "indigenous administration" on the other. ${ }^{1}$

In Belgium, the concept of development drove the success of domestic and foreign social sciences in universities. The nascent discipline of sociology in particular owes to it a kind of renaissance and an international opening up.

In the early nineties, this concept and its adjuvant "international development cooperation" came in for fierce and varied criticism: ecological, neo-liberal, theoretical (the decline of structuralism), and postcolonial. The theories of modernization and international development were already part of the history of the social sciences (Cooper and Randall 1997). Politically and scientifically, the notion of the Third World was in its death throes. Globalization established itself as a new paradigm.

The time had come to take a look back and examine the roots of the concept of development. Had it really been a historic rupture? Had its ambitions and theoretical and political limitations not been at the heart of colonial sciences and theories? It was by asking this question that, going back from the time of decolonization. I discovered the scale and institutional singularity of Africanist colonial science in Belgium.

\section{History as a Sociological Matter}

A sociologist by training, I was familiar with only a few Africanist studies from the 1950s. I was discovering that at the end of the nineteenth century, the sociology that was emerging in Belgian universities and intellectual circles was very much concerned with colonial debate and colonial opportunities. I was obviously discovering the birth of ethnology. I was also seeing the place claimed by sociology as the crucible of a science of colonization and of indigenous government that was still dominated by "legal sciences". I was emphasizing the very specific way of developing and institutionalizing Africanism in the shadow of a colonial power that can quite rightly be described as a colonial State in the State. The colonial sciences constituted obviously a specific and peripheral academy within the National Academy. Declared sociology initially appeared to be a kind of positivist insurance against the mystery of the "primitive populations" who no longer simply featured in the accounts of explorations. It was also a form of insurance against the belated, or perhaps spontaneous, challenge

\footnotetext{
${ }^{1}$ In the Belgian Congo, the first development plan dates back to 1949.
} 
of "creating a colony". Analysis and governance of the indigenous societies quickly triggered a diversification of ideological issues and of theoretical referents.

In this paper, I present research studies and analyses claimed by Belgian colonial sociology. This enables me to examine more specifically colonial academia. It was the very local incubator for an imperial "savoir-pouvoir" (Foucault) of governance and domestication. On a completely different scale, this process was analyzed mainly through its effects and cultural archetypes by postcolonial studies.

I attach great importance to time because it is very short. It is demarcated by polemics in response to the colonial crises. The colonial events are intense and dramatic and provoke heated debate among colonial scholars. They provide abundant material for analysis. I obviously stress the importance of the ideological configuration of the Belgian elites (Catholics versus Liberals), their need for international colonial legitimacy prior to the Crimes of the Congo campaign. But I also choose to highlight the contingencies, discontinuities and myriad growing tensions between officials in the Congo and those in Belgium. I draw attention to the restrictive and lasting rationales behind the creation of a specific institution: colonial academia. However, at the risk of shattering the image of a mechanism producing an all-powerful "savoir-pouvoir" institution, I do not underestimate the tinkering, improvisation, opportunism and disciplinary and generational rifts.

\section{An Unexpected Encounter}

Overall, the colonial era is easily demarcated. Belgium became politically independent in 1830. The Brussels Geographic Conference in 1876 can be considered the first public initiative stemming from King Leopold II's personal colonial projects. The Congo Free State (CFS), whose sovereignty over the Congo Basin was officially recognized internationally by the Berlin Conference (1885), conferred a second royal title on Leopold II: Sovereign of the Congo Free State. Until 1884, there was a succession of expeditions and voyages of exploration - primarily Stanley's "civilizing missions" and "scientific expeditions" - which set up posts in the Congo Basin. The fieldworkers involved in these missions were mainly of Belgian or European origin (Bederman 1989; Viaene 2008).

Following strong international criticism, especially by the Congo Reform Association (CRA), for which Robert E. Park worked early in his career, the CFS was "taken over" (this is the most commonly used term in Belgian historiography) in 1908 and became a Belgian colony under the name of the Belgian Congo (Marchal 1996). ${ }^{2}$ This episode ended in 1960, when the Congo gained its independence. So strictly speaking, Belgian colonialism covers a period of 52 years, or two generations; however, the colonial process that includes the King's expeditions in Africa and the CFS period spans a period of 84 years, from 1876 until 1960, or a little less than four generations.

\footnotetext{
${ }^{2}$ It was the only Belgian colony. Ruanda-Urundi became a "mandated territory" handed over to Belgium by the League of Nations in 1922. The Congolese army known as La force publique, whose leadership had increasingly been made up of Belgian officers since 1890, had conquered these German territories in 1916. In 1925, Ruanda-Urundi was administratively integrated into the colony, but kept its "mandated territory" status.
} 
In 1888, Leopold II offered to hand the Congo over to the Belgian state (Vandersmissen 2011). He obtained public funds from the Belgian state on several occasions. He received support from the Catholic Church and the Catholic Party and gave privileges to Belgian Catholic missions. Free trade deals were struck with other European nations, but he violated them by establishing his own monopolies. By way of an example, the private Crown Domain, where rubber was produced, saw acts of extreme and unprecedented violence.

Between 1878 and 1884. An elite group of "annexationist" publicists, businessmen, politicians and academics was formed. They promoted the ventures in the Congo and massively supported pro-colonial activities. They had to provide an answer to the longstanding sworn enemy of pro-colonial theory, liberal economic theories, while fending off an anti-monarchist left.

Among the Catholic elite, a degree of skepticism surrounded the King's African projects. However, by granting privileges to Catholic missions (until the 1906 Concordat) and appointing E. Descamps, an eminent Catholic lecturer from Louvain, as leader of the anti-slavery crusade, Leopold II managed to gain their support. The expansion of business opportunities for the Catholic bourgeoisie in the Congo sealed the deal. The Catholics had a major influence on the development of Belgium's colonial doctrine, although this would never be the only influence on colonial policy.

Like the 'freethinking' Liberals, the Catholic faction would not be unanimous on the colonial question. The takeover by Belgium disarmed the anti-Leopold II left. Promoting a national colonial doctrine was already a challenge for colonial interest groups, but the next challenge was more perilous: it involved constructing a colonial administration and a colonial legal system. The need for an indigenous policy quickly led to serious conflict between/within the colonial elites. The different theories were now to be supported by field observations, scientific analyses, and inter-colonial comparison. From 1908 to 1920 colonial sociology was a battlefield of "civilization" politics between Catholics and Liberals/Free-thinkers. Other battles followed regularly during colonial crisis. During the Great Depression of the 1930s, conflict opposed at theoretical level radical modernizers of agriculture and defenders of local crops. During the 1950s, local white social reformers were more critical of the power of Brussels than that of the big Congo companies. From this point of view, the colonial hegemony appears unstable.

\section{Colonial Sciences in Imperial Culture}

More than three decades of postcolonial studies have radically transformed the way we think about imperial sciences and their epistemology (Cooper and Stoler 1997) I shall not dwell on the stability and durability of this asymmetric colonial paradigm. There is nothing new to be learned from deconstructing again the dominant discourses. Instead, I focus on the local conditions underlying the production of colonial sociology. The uncertain processes involved in the institutionalization of scholarly practices, and the vagaries, unfounded or disputed claims, and inconsistencies of the knowledge to which these practices led, ultimately produce a picture that is quite different from that of a merciless subordination and domestication mechanism driven by an implacable "pouvoir-savoir" (Foucault). 
Even more than colonial history in general, colonial science was indeed the victim of a kind of voluntary amnesia after $1960 .^{3}$ One basic reason for examining part of Belgium's colonial sciences between the late nineteenth and the mid-twentieth century is historical: to analyze a part of the colonial culture which, paradoxically, has barely been analyzed hitherto. However, it can be observed that African scientific production has rapidly become very important and that the scientific compilation work, which I call encyclopedic, began very early on. The quest for international recognition fueled this need to compile the entire international bibliography on the Congo. Belgian scholars had to conquer empirically and symbolically the last unknown land": the Congo. Wauters and Buyl counted 3800 studies about the Congo in 1895 (Wauters and Buyl 1895).

After the downfall of CFS, Belgian colonialism aimed to be the most efficient and the most "modern" in Europe. The interests of industry and capitalism were summed up in one word: expansion! The colonial sciences were invoked to legitimize and inform Belgium's colonial expansion, which led to the creation of new scholarly institutions which eventually became more closely linked to colonial interest groups than to the national academic institution (Poncelet 2008; Vanthemsche 2012). Only a few individual links existed between the universities and these new colonial institutions. However, a unique field of the colonial sciences burgeoned, and it is in this context that contributions from the social sciences - especially sociology and ethnology - need to be situated and analyzed. 4

\section{Colonial Sociology?}

Colonial sociology/ethnology emerged along with Belgian sociology itself, and within the same small and elite circles as the Belgian colonial project. The links between colonial academia and colonial power remained close until the early 1950s. No independent colonial sociology existed before this time. It would, however, be erroneous to exaggerate coherence and continuity. It would also be dangerous to believe that there was any real scientific management of colonization. Colonial science was a centerpiece of ideology and of an all-powerful imperial attitude. It took significant place in Belgian knowledge institutions. However my particular goal is to go a little further behind the scene. I highlight the interplay of three tensions that reflect the singularities and limits of colonial sociology. The first one is the tension between scientific knowledge and ideology. The second developed between the ambitions of encyclopedic knowledge and social engineering. The third, that became a late break line, is between field observations of uncontrolled social changes (in Congo) and the institutional and interpretative frameworks in Belgium.

\footnotetext{
${ }^{3}$ After the Congo, Rwanda and Burundi achieved independence, a White Paper was published by the Royal Academy of Overseas Sciences (formerly the Royal Belgian Colonial Institute). It was the last expression of an encyclopedic obsession that had begun at the turn of the century. It ceded colonial science to the Africans, as though the Royal Academy wanted to be sure that they would be able to control their own destiny (KAOWARSOM 1962).

${ }^{4}$ For a discussion of European perspectives on colonial sociology, see Cohn (1996), Cooper and Stoler (1997), Hund and Lentin (2014), Leimdorfer (1992), Madan (1979), Sibeud (2002), Steinmetz (2013), Stoler (2013), and Zimmerman (2010).
} 
At the end of the nineteenth century, "sociology" was widely referred to by authors and in various documents. Although not well-defined and based on rough outlines of different paradigms, the prospect of a science of social relationships and institutions met with great success in intellectual circles. The boundaries between disciplines were not clearly defined. The purpose of this nascent science remained uncertain. In Belgium, in the universities, many of the pioneers were mostly lawyers and secondarily philosophers or both! But some, like De Laveleye, also described themselves as economists. He held a "chair of sociology" and contributed to European public debate that we would now categorize as political science (Vandersmissen 2011). Among Catholics, academic training placed great emphasis on philosophy.

The requirement for empiricism and inductive reasoning which appeared compulsory in these sociological projects was hardly ever met with consistency by their authors. Texts that referred to sociology already clearly tended towards the theoretical and avoided empirical constraints.

Paradoxically, the terms "ethnography" or "ethnology" were no more frequently used than "sociology" by the first authors to address colonial and African issues.. ${ }^{5}$ The first Belgian Sociology Society's very first research projects were, as we shall see, conducted using a questionnaire that was described as ethnographic. However, the authors of these studies sought contribute to the field of "sociological science".

The first work written by a famous ethnologist and missionary (Van Wing 1921) was entitled Etudes bakongo. Histoire et sociologie. It was a work of ethnohistory. Up to the 1950s, the study of African social and cultural institutions was interchangeably presented as ethnology or sociology.

Within colonial science, ethnology (what we now know as social or cultural anthropology) took time to free itself from the colonial framework. It was also slow in distinguishing itself from the cognitive frameworks of the sociologists of the time. Varied and sometimes uncertain, these frameworks were generally interpretive, comparative and highly focused on theorization.

Even the academic ethnology of the Catholics, which was very wary of sociological theories, be they positivist, materialist, historicist or organicist, never abandoned theoretical approaches (De Jonghe 1908). Only rarely did it value ethnography in its own right. It was not unusual for missionaries specializing in the study of African languages to call on sociology, ethnology and history.

So I've chosen not to apply contemporary disciplinary distinctions. I have not excluded from the scope of colonial sociology texts that professed to belong to this field. Except in the case of obvious misinterpretations and texts with no specific sociological content, I have examined texts that were considered to be as ethnological and/or sociological claiming to relate to colonialism and Africa. I've concentrated on authors who, in several texts and in different circles, presented parts of their work as sociological and/or ethnological. As we shall see, all Africanist knowledge was colonial. All, or almost all, colonial knowledge was Africanist.

\footnotetext{
${ }^{5}$ In French, which was the main publication language at the time, the term "anthropology" was used by doctors (physical anthropology) or philosophers (general reflection on Man) without any specific reference to a collective, social or cultural dimension.
} 


\section{Breaking Away from the Free State}

Among the contributors to the colonial debate - a hundred at most - four figures stand out on account of their position vis-à-vis the CFS and their adherence to the idea of a Belgian "takeover" of the Congo. For a variety of reasons, these four academics teamed up to oppose the CFS and Leopold II after 1900. Each of them saw what they called colonial sociology as an indispensable element in the exercise of the modern "right to colonize."

Félicien Cattier was a banker and professor of law at the Université Libre de Bruxelles (ULB). He had been involved in the colonial projects of the Banque d'Outre-Mer (Bank of Overseas). Working in Edmond Picard's office, he had also been the architect of the CFS legal system. He was not afraid to talk about colonial sociology and helped to design the first ethnographic surveys of the Société d'Études Coloniales. He was also a regular contributor to the Société's reports and to the geographical journal Mouvement Géographique, which was founded by A.J. Wauters. Yet, as far as theory and practice were concerned, the leader of the ULB colonial group remained in favor of a liberal legal system (Cattier 1906). Cattier joined the Colonial Council in 1912 and became head of the colonial branch of the Belgian bank Société Générale in 1926.

Émile Vandervelde combined an academic career with a political career. He worked as an academic at the ULB, but he also held the position of President of the Second International (1900-1918) and of the Belgian Labor Party (1933-1938). He opposed the King's attempts to expand his constitutional powers through the creation of the Congo Free State and objected to the privileges that the King had granted to Catholic congregations. Vandervelde joined the Congo takeover movement. In his view, there was nothing to indicate that France, Germany or the United Kingdom would handle the Congo any better than Belgium, but the Catholic activities and interests had to be cut back. Despite his anti-colonialism, he believed that the colony provided opportunities and responsibilities for the Belgian nation (Vandervelde 1911).

Although he was not an academic, Cyriel Van Overbergh was the driving force behind the first Belgian Society for Sociology and its journal Le Mouvement Sociologique (Vanderstraeten and Louckx 2018). He was a senior government official and member of the Catholic Party. In 1904, with the help of Joseph Halkin and Achille Camerlynck, Van Overbergh started to design a wide-ranging ethnological survey questionnaire. After negotiations with Leopold II, the survey questionnaire was administered on a broad scale in the Congo. Van Overbergh was (co-)author of 11 monographs on Congolese tribes that were based on the findings of the survey. The monographs provided, among other things, detailed information about local African languages. In 1905, Van Overbergh also founded the Bureau International d'Ethnographie, whose role was to coordinate European ethnographic research. Its head office was located in Belgium; its official journal was the Mouvement Sociologique International. Throughout his work, Van Overbergh defended the idea that sociology and ethnology would be as indispensable to colonization as soil chemistry to agriculture. But two considerations needed to be taken into account: social sciences had to rely on empirical surveys which provided systematic, comparatively oriented knowledge, and in addition, preference had to be given to systematic and inductive methods rather than to the application of rudimentary theories. Van 
Overbergh believed, moreover, that his scientific initiatives would help to justify the colonial doctrine of Belgium and its Catholic Church.

Finally, the Jesuit Arthur Vermeersch, was trained as a theologian. From 1906 onwards, he developed an interest in the African question and published La Question Congolaise, in which he was critical of King Leopold II's schemes and argued in favor of a Belgian colony (Vermeersch 1906). For Vermeersch, Belgium was morally obliged to annex the Congo in order to eradicate the problems created by the Leopoldian system. At the same time, he seemed well aware of the challenges that the Congo presented for the Belgian Catholic missions and their missionary work. He visited the Congo in 1913-1914. Between 1923 and 1924, he taught moral theology as well as sociology and canon law at the Pontifical Gregorian University in Rome. In the Belgian Catholic context, he introduced a critical position based on history and morality.

\section{The Crime of the Congo}

From 1905 onwards, international reaction to the atrocities committed in the Free State, and particularly in the Crown Domain, developed into a Western humanitarian campaign. According to some, it was the first professionally conducted international humanitarian campaign in history (Clay 2016). Founded, among others, by the British journalist and politician E.D. Morel, the Congo Reform Association had the explicit intention of exposing abuses by public servants in the CFS and calling for drastic reforms (Hochschild 1999; Bevernage 2018).

To assess the scale of this humanitarian and anti-imperialist campaign, we only need to think of Mark Twain's King Leopold's Soliloquy (1904), a fictional monologue of Leopold II speaking in his own defense. Twain maintained close contact with Morel and the CRA. Conan Doyle's pamphlet The Crime of the Congo was published in 1909. This campaign also drew attention to Joseph Conrad's novel Heart of Darkness, first published in 1899. Conrad had visited the Congo himself on behalf of a Belgian trading company.

Although he had never been to the Congo, Robert E. Park became the first secretary of the CRA's American branch. Park maintained contact with the CRA in London, particularly after Morel's visit to the USA in 1904. During his early career, Park authored four essays on the tragic situation in the Congo under the CFS (Lyman 1990). His fifth text on the Congo was published by Booker T. Washington, for whom he worked as secretary at that time.

Using a Gothic metaphor of horror, Stanford M. Lyman suggests that Park's early papers on the Congo be seen as a radical examination of the inhumanity of imperial capitalism (Lyman 1990, 1991). By highlighting the double-sided moral character and socioeconomic effects of the Reformation, Park, according to Lyman, questioned Max Weber's famous thesis on the Protestant ethic and the spirit of capitalism. His portrait of Leopold II and his CFS (A King in Business, as he titled one of his essays) is designed to show how the civilizational process erodes the many folk cultures that it incorporates. Therefore, Park's essays on the Congo need to be read together with his work on racial issues in the USA (see also Lösing 2014). 
Although discussion about the Crime of the Congo took place between the CRA and a few Belgian scholars, not a single Belgian sociological text from that period includes a fundamental critique of imperial capitalism. Although different socialist schools of thought had emerged in this small (and at that time) hyper-industrialized country, Belgian scholars proved unable to examine in any great detail the premises of the colonial paradigm.

Yet, a substantial section of the press vehemently condemned Léopold II's African activities. Paradoxically, national and particularly international condemnation of the crimes of the CFS defused more fundamental criticism of colonial imperialism. Amid a climate of colonial competition, the Congo Reform Association's campaign led to selfcensorship in Belgium. It was all the more powerful because an ideological and trade hub supportive of colonization had developed in Léopold II's shadow among liberal professors at the ULB. Therefore, A.J Wauters, the most prolific of geographers on the subjects of Africa and colonialism, and a craftsman who became an opponent of the Congo Free State, thanked E.D. Morel for the CRA's campaign. But he did that after the takeover!

\section{Congo Makes its Appearance in Universities}

In the Belgian academic system, proponents of economic expansion often became proponents of overseas colonization. In their view, industrial expansion on the global scale made modern colonialism necessary. Many scholars also argued that research had to be linked with the "right to colonize" and the "call to civilize." Although every Belgian university had its colonial experts and colonial curriculum, they did not include much sociologically and ethnologically oriented Africanist education and research in the period leading up to the CFS's annexation in $1908 .{ }^{6}$ Nonetheless, the most influential academic networks on the topic of Africa developed in Brussels and Louvain.

At the University of Brussels, the colonial network was relatively large, thanks to the presence of illustrious figures such as Camille Janssen (who held the position of Governor-General of the Congo Free State from 1886 to 1892) and Albert Thys (who, as a businessman, was omnipresent in the CFS). Both Janssen and Thys were active supporters of Leopold II's projects in Africa. This network also included F. Cattier and other members of the International Colonial Institute who had been the architects of the annexation and nationalization of the Congo Free State by the Kingdom of Belgium.

In addition, in 1909, Émile Waxweiler established a colonial studies group (Société d'Études Coloniales) at the Solvay Institute of Sociology in Brussels. The geographer A.J. Wauters was the driving force of the Société. This group tried to combine independent field ethnography and functional sociology in the tradition of Waxweiler

\footnotetext{
${ }^{6}$ At the State University of Ghent, Charles De Lannoy set out to establish a so-called "colonistic" science that would encompass colonial sociology. At the State University of Liège, Ernest Mahaim, who succeeded Emile De Laveleye as Chair of sociology fully justified the colonial doctrine with its focus on expansion and on the civilization of the Congolese indigenous population. In his view, colonization was not at odds with national social policies. He was Minister of Industry and Labor after the Great War and, in 1931, would become President of the International Labor Organization (ILO).
} 
in order to draw up indigenous policies (Crombois 1998). Unlike Cattier, some members of this group were supportive of forced labor and of the civilization ideas/ practices of the Catholic missionaries (Hund and Lentin 2014). After Waxweiler's death, this colonial group remained active at the Solvay Institute of Sociology until the Congo achieved political independence (Rubbers and Poncelet 2015). ${ }^{7}$

The Catholic University of Louvain did not unanimously support the King's ventures; neither did it consistently support the development of sociology. For the religious authorities, the study of "primitive people" posed obvious problems. However, at least three factors need to be taken into consideration to understand the importance that would be attributed to ethnology and colonial training at the Catholic University of Louvain.

The first is the unprecedented missionary focus on Central Africa. The second relates to Édouard De Jonghe, who was omnipresent in Louvain for 40 years, notably at the Tervuren Colonial Museum and several colonial institutions. He even became a director at the Ministry of the Colonies. In the tradition of Van Overbergh and Halkin, he promoted detailed ethnographic recordings of Congolese tribes (De Jonghe 1920; Couttenier 2005). Although he never did much fieldwork and only made one short trip to the Congo, he became a tireless instructor of the Catholic missionaries, whom he wanted to familiarize with ethnography. He involved several of them in his ethnographic projects. He was also uncompromising in his defense of the exclusive right of the Catholic Church to control Congolese school education.

The third element relates to Edmond Leplae's work in tropical agronomy. In a way, Leplae was to agricultural sciences what De Jonghe was to Catholic colonial science. Like De Jonghe, he became a director at the Ministry of the Colonies. He was omnipresent in rural politics; he assumed responsibility for management of the Congolese plantations in 1926 and produced the Bulletin Agronomique du Congo Belge. Leplae was also the founder of the National Institute for Agronomical Study of the Belgian Congo in 1934. With De Jonghe, he promoted the idea that scientific insights could help turn around indigenous social and cultural traditions. Links between the Colonial Office and the Catholic academic world remained strong for more than 25 years.

The convergence between the views defended in Louvain and official colonial sociology played an important role in the articulation of a colonial ideology that, around 1935-1940, focused on "civilization through work." However, rural policies in the Congo have never been based on well-articulated theoretical models. Much to the contrary, the system of surveillance that was put in place allowed some agronomists to assemble 'sociological' data.

On the field, the policeman-agronomist existed alongside the agronomist-turnedamateur-sociologist! This opposition between the partisans of an agricultural revolution and the partisans of endogenous development was perceptible throughout the colonial academia in Belgium.

\footnotetext{
${ }^{7}$ The importance of sociology and ethnology for colonial politics was later emphasised at theoretical level by George Smets, who was Director of the Solvay Institute of Sociology from 1935 to 1952. Arthur Doucy, who was Director from 1959 to 1980 , was a key actor in the transition of Free Brussels Univesity from the colonial sciences to the sociology of development.
} 
The university programs of colonial training were a motley crew. Altogether, only a few students studied colonial sciences or tropical agronomy before 1920. There was no clear recruitment policy for the colony. Plans, which existed at the time of the takeover, for a global colonization school under the auspices of the Brussels Bureau International d'Ethnographie faded in the years before WWI (de Bie 1988). Programs to tackle the challenges of the takeover, including the establishment of a colonial administration, could not be organized easily in Belgium. In fact, the annexation of the CFS took a long time. Before 1925, administrators and missionaries created their own practical knowledge. They were more influenced by their basic training and by shared colonial ideology than by colonial sociology or academic ethnology. Colonial sociology, as propagated in the Belgian universities, did not pay much attention to the human and social chaos in the Congo (Hunt 2016).

\section{Ethnology and Colonial Doctrine: Academic Debates}

From 1914 until 1918, the Great War took place in both Europe and Africa. Due to the war, the transformation of the CFS's militarized administration into a colonial administration took a long period of time, more than 10 years. During this period, colonial debate in Belgium was largely suspended.

Belgium's colonial doctrine was re-affirmed after the war, but debate among colonial scholars took another form. Much greater emphasis was placed on in situ observations conducted by a new generation of magistrates, bureaucrats and missionaries with extensive field experience. With regard to sociology and ethnography, this new generation was obviously self-taught, yet they fiercely claimed to be adherents of these disciplines so as to justify the originality of their argument. While they shared ideas about racial distinctions and primitive societies (see below), they often diverged with regard to indigenous "civilization" policies. Using historical and sociological analyses of different Congolese tribes, some of them stressed the detrimental effects of colonial policies (e.g., Van der Kerken 1920; Van Wing 1921). Others continued to emphasize the civilizational effects of Belgium's colonization and annexation policies. The discussion and debate, which in some respects transcended the traditional ideological opposition between Catholics (with an interest in evangelization) and 'freethinkers' (with more "realist" concerns), lasted until the 1930s. They more or less disappeared when an agreement was reached on so-called "indirect rule" (retaining local traditional leaders in positions of authority under colonial oversight).

The debate led to the formation of distinct cliques in the colonial institutions, which had a long-lasting impact on ethnological and sociological research in the Congo. From the 1920s onwards, however, some new principles were accepted in Africa. The overarching interest in encyclopedic knowledge was generally replaced by an interest in "real" knowledge. It became no longer possible not to base research on extensive fieldwork. Training in ethnography became essential scientific capital. Against this background, one must understand the networks within which knowledge and men began to circulate between the Congo and scientific institutions in Belgium. A double division of academic work and knowledge began to develop: between the ideological 
networks, on the one hand, and between colonials in the Congo and those in Belgium on the other.

If the creation of a new discipline, sociology, seemed urgent in the nineteenth century for a small group of academics and social reformers, the urgency was obviously a reaction to the social, political and cultural changes that European societies were undergoing at that time (Heilbron et al. 1998). The demand for social knowledge also reflected ambitions to intervene in these societies. In the eyes of the first sociologists, political-interventionist ambitions were compatible with claims to objectivity. 'Pure' science and 'applied' science were considered inseparable.

The same ambitions existed for colonial sociology, however this specialization was defined. Time and again, modern colonization was said to require input from science, including social science. Colonial ideology and positivist ideals were perceived to be intimate partners (even if it was questionable whether the colonial sciences had a direct influence on colonial policy). The importance of colonial sociology could, therefore, easily be affirmed in Europe and Belgium at the turn of the century. Colonial sociology could present itself as a discipline in its own right.

The Belgian Catholics, who had difficulty with the supposed secular aspects of sociology, often preferred to invest in the development of ethnology (instead of colonial sociology). For De Jonghe, who was the most influential Catholic ethnologist in Belgium at the time, ethnology was about patiently completing the great encyclopedia of the different peoples and their cultural developments. He had been a follower of Van Overbergh, the founder of the Belgian Society for Sociology; he had also been involved in the publication of the voluminous ethnographic monographs that were based on the findings of Halkin and Van Overbergh's ethnological survey questionnaire. When it came to characterizing indigenous peoples, he was as opposed to LévyBruhl's theories as to the functional theories of the Solvay Institute. He rejected approaches, of African tribes as "uncivilizable" and instead repeatedly justified evangelization by claiming that, before the colonial interventions, African cultural institutions were undoubtedly in a state of decadent decomposition. Curiously enough, he also presented colonization as something serving the interests of a universal ethnology rather than the other way around.

De Jonghe was able to train dozens of missionaries for systematic ethnographic fieldwork. With the help of a few missionary-ethnologists, such as Joseph Van Wing, he established a powerful network that could undertake colonial ethnographic studies. Several other Catholic academics (philosophers, jurists and historians) joined his projects, too. For about a quarter of a century, this network played an influential role in Belgian colonial sociology. De Jonghe and Van Wing were key figures in colonial sociology from the real takeover (1920s) to the 1950s. They were the brokers between the missionaries in the Congo and the few colonial researchers who held academic positions at Belgian universities, such as Joseph Maes or Théophile Simar.

The main challengers of this Catholic ethnology and sociology were liberal intellectuals. At the Solvay Institute of Sociology in Brussels, Waxweiler found his ethnologist-fieldworker in the person of Adolphe De Calonne Beaufaict. De Calonne was a self-taught engineer who had a fascination with the populations of the northeastern parts of the Congo. He practiced ethnography, published two influential books and was coopted by the Ethnological Society of Paris. Before the outbreak of WWI, Waxweiler and De Calonne Beaufaict strongly opposed "assimilationist" ideals, based 
on the exportation of European norms, the direct rule of African people and - last but not least - Catholic evangelization practices. Instead, De Calonne placed great emphasis on the longevity and functionality of African traditions of social control, such as the institutions of chiefdom and secret societies. Due to the early death of both protagonists (De Calonne died in 1915, Waxweiler in 1916), however, this line of ethnological research could never be fully developed at the Solvay Institute of Sociology in Brussels.

Just as for the Catholics, ethnological work and in situ experiences also became more important for the Liberals and 'freethinkers.' Colonial magistrates and civil servants, such as Paul Salkin and Georges Van der Kerken, painted a grim picture of colonial policies. Along with other self-taught social scientists, they questioned the activities of the religious missions and condemned the lack of realism of the first colonial law reforms (1910). Salkin based his 'sociological' view on the 'discovery' of the longevity and stability of African social institutions, which fascinated many Europeans at that time. At the same time, this view was fueled by the fear of cultural, moral and biological contamination. According to Salkin $(1920,1926)$, ethnology had to identify the basic distinctions between races. Colonial sociology, for its part, had to inform a colonial policy of minimal intervention known as "recueillement" (contemplation).

Building on his legal work in Katanga, Van der Kerken also sharply criticized Belgium's colonial policies. He highlighted the hidden resistance of the key legal and political institutions of local societies to uncertain reforms (Van der Kerken 1920). In his opinion the aims of the first colonial laws were unrealistic and inappropriate. In both his view and that of Salkin, the collapse of social and political rules was imminent in Central Africa. But unlike Salkin, who defended a belief in racial and cultural incompatibility between Europe and Africa, Van der Kerken tempered his criticisms. He endorsed the aforementioned colonial consensus (Van der Kerken 1944).

Colonial sociology and ethnology in Belgium never gave up their ambition to be simultaneously practical and encyclopedic sciences of African populations. Within both ambitions, however, different views were expressed with regard to the articulation of these ambitions. The different views partly corroborated the ideological opposition between Catholics and Liberals, between "civilizers" and partisans of limited interventions in African societies. These differences came more strongly to the fore after the end of WWI, when increasing emphasis was placed on the socio-historical identity of African societies and the negative impact of colonization activities. But not until the late 1950s and 1960s did it become possible for Belgian social scientists to analyze colonialism itself from an independent sociological perspective.

\section{Race and "Milieu"}

The notion of race had been omnipresent in colonial studies for a long time, carried many different meanings and was almost never clearly defined. Today it can be argued that it was typically used as an equivalent of terms like "society" and "culture." It was not uncommon for peoples, nations and ethnic groups to be referred to as races. Reacting to French colonial policy, Durkheim himself claimed that one could not 
disrupt the continuity of a race, by which he meant that the social institutions characteristic of a human population could not easily be changed (Lehmann 1995).

If we consider racism as the depiction of human groups or populations as being ultimately distinct and unequal, the colonial sciences were undoubtedly racist. Despite other differences, most of its scholars could agree on these presumptions. In-depth studies of languages, institutions and cultures did not prevent them from referring to the "Congolese race," "Bantu races," "nigger races," and so on. De Calonne Beaufaict (1912), for example, showed deep sympathy for African indigenous societies and explicitly intended to save them from destruction and evangelization, but remained attached to racist ideas about hereditary mental constitutions.

The notion of race was ubiquitous in Catholic networks. De Jonghe's ambition to 'convert' missionaries into ethnographers was relatively successful in the $1930 \mathrm{~s}$. In ensuing studies, racial concepts were widely used and examples of racial prejudice were legion. At the same time, however, racism was mostly unacceptable to the supporters of "soft evangelization." Many Catholics condemned the hypothesis of a fundamental primitive mentality (Lévy-Bruhl) inaccessible to God's word. The notion of the "semi-civilized" (évolué) also appeared less dramatic to them. Among Belgian Catholics, Simar (1922) was probably the first to argue against colonial 'raciology' and against the political mobilization around racial differences.

Similarly, many Catholics had difficulty in treating traditional societies as fundamentally immoral. "Soft Christianization" by means of "endosmosis" seemed legitimate on the basis of ethnographic discoveries. But the notion of race had its place in this project. It appeared to be a realist point of departure, on the basis of which consensus could be achieved among the colonizers (see also Bancel et al. 2014).

Alongside race, environment ("milieu") was another key notion in early colonial social sciences. This "native milieu" or "indigenous milieu" was thought to reside in the kidneys and heart. It seemed unavoidable that it would have to be taken into consideration to achieve effective civilization. "Milieu" stood for the collective representations of ethnic populations; it indicated what was resilient within the indigenous people. To find openings, ethnology could again be called upon, although the aims had to be moderate. To find routes towards successful evangelization, one had to adapt to some extent to the social basic structures of the existing "native milieu".

\section{The Golden Age of Colonial Sciences}

In the years before the outbreak of WWII, the Belgian 'nationalization' of knowledge about the Congo and Ruanda-Urundi appeared to be close to success in both Dutch and French. Publishing channels for academic texts written in Dutch had increased, particularly in the Dutch version of the official colonial journal Onze Kongo/Kongo and in Catholic publications. Despite some scholarly debate, several institutions for the colonial sciences were established. While indigenous traditions were treated with some respect, the right/duty of the Catholic Church to evangelize was not fundamentally questioned. The Africans had few social and citizenship rights. In the Congo nobody voted! But increasing attention was directed towards the labor force. The Congo was to become the second largest economy in Sub-Saharan Africa. 
As already mentioned, the polemics about colonization policies in Belgium were influenced by ideological cleavages. Opposition to assimilationist doctrines and evangelization was relatively strong among Liberals; scholars such as P. Salkin and G. Van der Kerken questioned the solidity of the colonial edifice. In the decades between the world wars, discussions on the detrimental effects of these policies by Catholic scholars, such as the Jesuit J. Van Wing (1921), were based on more detailed knowledge of local institutions in the Congo. Van Wing underlined the historicity and longevity, complexity and strengths of these institutions. Several other highly trained missionaries also contributed to this line of argument. Using the numerous local studies by field missionaries, they published ethnological and linguistic studies that traced the history of different Congolese institutions. Much of this work was published in Notre Congo/Onze Kongo, the official colonial review, edited by De Jonghe and widely read in Catholic circles throughout Europe. The so-called 'missiology weeks' organized by the Catholic University of Louvain also played a considerable role in structuring and disseminating the ethnographic studies of the Catholics missionaries.

Eventually, the field ethnographers became involved in the colonial institutions in the metropolis. They joined the four major institutions that provided support for the colonial sciences in this period in Belgium: the RBCI (Royal Belgian Colonial Institute), the International Colonial Institute (ICI), the Colonial University and the Belgian Colonial Congress (BCC).

After 1935, Catholics and Liberals had a significant influence in these institutions. The RBCI, which was the main institution, had a "class of moral and political sciences." The ICI organized international sessions on topics related to (international) colonial policies, business, and law. The BCC regularly organized sessions to fine-tune and implement the Belgian colonial doctrine and policies. Its Bureau also produced large-scale colonial studies. Within these institutions, the ambition to maintain a national consensus on colonial policies was translated into a policy to ensure a balanced representation of Catholic and Liberal researchers.

The Colonial University in Antwerp, which was in no way a 'normal' university, took responsibility for the training of senior officials of the colonial administration. Although some of its lecturers produced hotly disputed theories (e.g., Habig 1948), this institution played an important role in the circulation of high-level colonial staff and practical colonial rules between Africa and Belgium. The Belgian universities themselves did have a voice in the ongoing debates, but they had only a very limited capacity to carry out research in the Congo.

The 1930s economic crisis sparked controversy about the well-being of rural populations in the Congo. With the creation of the INEAC institute for agronomic study in the Congo, Belgium aimed to solve the problems affecting rural life. ${ }^{8}$ E. Leplae's solutions won the day (see above). The position of the policeman-agronomist was thus added to those of the missionary-instructor and the omnipresent land administrator. Crawford Young, a political scientist at the University of Wisconsin-Madison, spoke shortly after the decolonization period following Belgium's panoptic control

\footnotetext{
${ }^{8}$ INEAC stands for Institut National pour l'Étude Agronomique du Congo belge. Its creation was part of a larger indigenous peasantry program, which aimed to modernize local agricultural practices by assigning plots of land to individual families and providing support in the form of selected seeds, fertilizers, and so forth.
} 
over the Congo, which, once fixed on a given course by a set of burdensome regulations, had proved incapable of altering its direction (Young 1965).

Before WWII, less pessimistic views on colonization were predominant in Belgium. It was widely believed that ongoing ethnographic and sociological work was helping to manage the Congolese territory and the Congolese population. The doctrine of agricultural improvement dovetailed well with the new pragmatism of the Catholic evangelizers. Labor had become key to the civilization project, in a broad sense. Only primary and vocational education were provided. The Catholic schools had a monopoly (Yates 1976; Depaepe and Van Rompaey 1995; Poncelet et al. 2010). Bantu languages were used in these primary schools. In the view of many observers, progress was being achieved in the Congo and the colonial sciences.

\section{War Debts: "We Can't Do this to Black People Anymore" (Ballegeer 1946)}

Belgium and the Congo grew apart somewhat during WWII. During the same period, broader international developments in social and cultural anthropology had an impact on Belgian universities and colonial institutions. The decolonization process had begun in Asia. After the Holocaust, the term "race" had become very sensitive in the West. These shifts had a strong influence on colonial ideology and at times gave rise to extravagant theories. $^{9}$

The publication of Bantu Philosophy by the Franciscan missionary Placide Tempels in 1945 was symptomatic of the shifting views on colonization (Bontinck 1985). Tempels presented a new perspective on Catholic evangelization based on the distinctiveness of the "philosophy" of the Bantu people (Tempels 1959). In this view, the African mentality was different from the European one. But he questioned the distinction commonly drawn between the civilized Christian Europeans, on the one hand, and the primitive pagan savages, on the other. According to Tempels, Europe had to admit its ethnological mistakes. Bantu philosophy and Catholic evangelization had to become inseparable. A 'fair' appreciation of indigenous Bantu ways of thinking had to illuminate colonial policies and missionary evangelization (see also Vinck 2000).

Although Bantu Philosophy was not well received by the Catholic Church, it did lead to much discussion about the Church's policies in Africa (and other colonized territories). With input from other ethnologist-missionaries in the field (so-called "bush fathers," most of whom were Flemish) a new perspective on African cultures gradually developed. For many of them, De Jonghe's attempts to produce a systematic ethnography of indigenous cultures in Africa no longer sufficed (e.g., Maquet 1949). Although this struggle initially took place within the Catholic Church in Belgium, it soon also affected the legitimacy of the entire colonial doctrine. The basic principles of Belgium's colonial ideology were increasingly called into question.

Changes in the Congo also played an important role (Van Wing 1951). WWII is sometimes described as a period of "back to rubber collection," i.e. a return to forced labor. The post-war years marked the beginning of a new period with regard to colonial

\footnotetext{
${ }^{9}$ Faced with international criticism of the race concept, the military doctor J. M. Habig (1948), for example, tried to combine cultural relativism with racial conceptions of people and history.
} 
governance and Africanist knowledge. Local colonial governance established itself after the so-called "war debts" campaign in Katanga that was designed to 'compensate' for the many African contributions to the war. An international climate of emancipation enveloped the colonies. Colonial sociology, which was sometimes difficult to distinguish from ethnology, linguistics, missiology and indigenous politics, became more tangible. It should be noted that, as an empirical science, the discipline started to receive more attention. It demanded and obtained research resources and specialized teams. Work, social policies, housing, professional training, internal migration control and urban planning were at the heart of this revival. The influence of American sociology and anthropology became evident in both Europe and Africa.

Two historic rifts must be discerned with respect to this scientific reinvestment in colonial sociology. The first of these rifts is both social and ideological. The authoritarian colonial model of "civilization through labor" and gradual cultural integration seemed incapable of fending off the detrimental effects of industrial development on traditional societies. The second aspect of the dispute among the colonial elites was the discovery of the impotence of the so-called indirect rule governance model (which it never really was). It was held responsible for the chaos in both urban and rural areas. The best response to this crisis was thought to be a new type of colonization policy: "colonization for development." Once again, specific scientific expertise was required to manage the rapid social changes brought about by economic growth and urbanization (Forde 1956).

\section{Professional Anthropology and Applied Sociology}

Faced with the "war debts" campaign and rapid industrial changes in the Congo, Belgium eventually channeled more resources into its colony, particularly into Katanga (with its copper and cobalt mines). The Congo had not cost much so far; Belgium was indebted to the Congo. Belgium responded with a 10 -year economic and social development plan (1949). It focused on house building, energy supply, rural development and health-care infrastructure. In 1948, the Belgian government also created a new multidisciplinary research institute, IRSAC (Institute for Scientific Research in Central Africa). In the social sciences, the new Centre d'Étude des Problèmes Sociaux Indigènes, in which all Belgian universities participated, but which was also supported by large corporations such as the Union Minière du Haut-Katanga, played a pivotal role (Clémens 1959; Rubbers and Poncelet 2015).

The Congo had to change - and the same was expected of colonial science. Traditional forms of colonial ethnology and sociology not only had to give way to new 'scientific' approaches (as argued by Tempels and others), but also to social action. ${ }^{10}$ New plans for social engineering were announced. The ambitions of the many newcomers in the Congo's research institutions were at times extraordinarily high - but their blind spots were also large (e.g., Brausch 1961).

\footnotetext{
${ }^{10}$ The number of publications devoted to social change in Africa began to multiply during the post-war years. It was a dominant topic among renowned authors and newcomers alike (e.g., Maquet 1949; Forde 1956).
} 
Specifications for new IRSAC recruits were two-fold: to renew knowledge of social and human problems and to support the development of the Congo. Scholars, such as Jacques Maquet, Jan Vansina, Daniel Biebuyck and Luc de Heusch, started their research careers as IRSAC pioneers. Recruited from outside colonial circles, they steered clear of the many polemics about Belgium's colonial policy. In line with international developments in the social sciences, they invested a great deal of time in anthropological fieldwork. After Congo had gained its independence, they turned to international academic careers in Africanism (see Vansina 1994). ${ }^{11}$

In the case of the IRSAC, the rupture with the colonial sciences of the pre-WWII era was relatively vehement, especially in terms of research methodology. In the case of CEPSI, this rupture was less obvious. Many colonial ambitions and prejudices survived. Field knowledge and field experience no longer constituted indispensable symbolic capital. Ethnological sympathy with indigenous cultures was not considered appropriate. The main fields of action for these sociologists and anthropologists were urban and suburban areas of Katanga. Research often also went hand in hand with social/sociological experiments: social homes, urban gardens and neighborhood groups (Wallerstein 1963). The experiments could be sizeable, such as the creation of a belt of suburban cities to help migrate "Bantu people into modern social life"!

René Clémens, for example, set up an experimental station in Mangombo. For Clémens, who had founded the Institute of Sociology at the University of Liège in 1955, and at that time also joined the CEPSI, this station had to be a "Bantu kibbutz." As an experiment in modern African agriculture, it had to provide food for the urban areas. The "kibbutz" idea was characteristic of the demiurgic, authoritarian and scientific modernization utopias. Agronomists, psychologists, educators and sociologists organized this "new community." Nutritionists and sociologists also worked together to study cooking, eating and domestic habits in cities and labor camps (Poncelet 2015). ${ }^{12}$

Under the direction of Belgian sociologists, about 30 young academics began their careers in the Congo during the last years before the Congo gained political independence. Given the scale of Belgian sociology at the time, this number was not insignificant. A few 'outsiders' were able, in their work, to keep more distance from the demands for social engineering and control in the Belgian colony (e.g., Caprasse 1959; Benoit 1959; Richelle 1960; Minon 1960). Some of them were later able to make a career in the universities ... but far from Africanism.

The new, post-war generation of Belgian researchers replaced the former ones, but there were still no signs of any Congolese university-level expert. With only a few exceptions, such as the Rwandan priest and intellectual Alexis Kagame, Africans of the "Belgian Empire" made no written contribution to Belgian Africanism before independence!. Altogether, the Congo became a topic of much debate in the Belgian academic

\footnotetext{
${ }^{11}$ It might be added that the work of these schoars was often at odds with the leitmotif of their employer (IRSAC), which was to base colonial development on a scientific aggiornamento.

${ }^{12}$ Under the direction of Arthur Doucy, the Solvay Institute of Sociology also set up studies into urban and labor policies in Katanga (see Doucy 1957; Rubbers and Poncelet 2015; Bouvier 2015). In the historiographic literature, the Chairs of the institutes of sociology in Liège and Brussels, Clémens and Doucy, do not so much stand out for their contributions to colonial sociology as for their political interventions. Clémens played an important role in the Katangese secession (Kennes 2014), while Doucy became an advisor to Zaïre's President Mobutu.
} 
world in the post-war era, but from a Belgian perspective (Vanthemsche 2012; Van Reybrouck 2014).

So the new sociology of post-war changing Congo remained largely Belgian through its researchers. They looked beyond the colony and beyond Belgian academic science (Fox 1994). However, even in hand of newcomers, the sociology of Congo post-war development remained a world apart in Belgian universities. The new approaches did not seem capable of bridging the epistemological gap between study of colonial Africa and European societies. The concept of development itself has remained dual.

\section{Decolonizing Congo}

Belgian ethnologists and sociologists published critical observations and reflections on the negative effects of colonization in the years after WWII, for example the lack of social mobility for Africans or land policies. A form of Apartheid existed in the Congo, the so-called color bar. There were calls for the extension and protection of social rights. The "depopulation of the bush" became an obsession; urbanization processes seemed uncontrollable. However, in the mid-1950s, the anti-colonial movement was neither powerful nor radical. Between 1955 and 1958, many Belgians and many researchers continued to believe in the future of development colonization. They saw independence in a distant future. Regardless of international political developments, Congo's strong economic growth and the impressive development of the industry since the beginning of the 1950 s seemed to provide some guarantees. A few dozen researchers were working on the field! Although the British Africanist Basil Davidson criticized Belgium's political blindness to the civil rights of the indigenous people, he also spoke highly of the way the labor force was managed by colonial companies and colonial administration. According to Davidson (1955), no other indigenous working class in Africa was as efficient as the Congolese one.

For most insiders, the riots which broke out in January 1959, first in Léopoldville (Kinshasa) and later in other parts of the Congo, and which would lead to the political independence of the Congo in June 1960, were largely unexpected. Neither the political nor the academic world was prepared for the decolonization of the Congo (and of Ruanda-Urundi 2 years later).

In the mid-1950s, the Catholic Lovanium University - named after its founding institution, the Catholic University of Louvain -was opened in Léopoldville (Kinshasa). At Lovanium, the historian and political sociologist Benoît Verhaegen undertook detailed studies of and actively contributed to the decolonization process in Central Africa. Adopting a Marxist perspective, his Centre d'Études Politiques at the Lovanium documented the conflicts and revolution in radical terms. Many of these studies, which cover a period of nearly 10 years, were produced in collaboration with the nonacademic Centre de Recherche et d'Information Sociale et Politique in Belgium (directed by J. Gérard-Libois). However, the 'fertility' of their Marxist account of the African decolonization conflicts did not tally with their many empirical findings and insights (see Demunter 1975; Ndaywel è Nziem 2006; de Villers 2011).

The field research (and action research) of Verhaegen and his collaborators contributed to the growing international interest in African political sociology (e.g., Young 
1965). Obviously, the violence and internationalization of the Congo Crisis (19601965), as well as the new, independent nation's dramatic trajectory, has continued to generate academic interest in Central African politics in more recent years (e.g., Englebert 2009; Schatzberg 2012; Hunt 2016). The options pursued in recent scholarship go beyond the Marxist and Third World ideas that were defined by the Cold War era and propagated by Verhaegen. The new options and approaches have enabled important innovations in African political sociology. In contrast to the forms of colonial sociology which predominated in Belgium until the late 1950s and early-1960s, they include the political mobilization of the African populations.

\section{Conclusion}

Although it was a personal project of King Leopold II, the CFS was nationalized from an early stage in some circles among the political elite. In the institutional framework of a singular colonial Academia, colonial sciences played a key role in legitimizing Belgium's colonial "vocation" at international level. Most scientific work initially focused on the completion of the Congo encyclopedia. A large amount of bibliographic information was gathered. Much attention was also directed towards controlling the production of data by Belgian explorers, administrators and missionaries. Colonial Academia was the template for all Belgian Africanism, in all disciplines of the natural and human sciences.

Colonial sociology was not the product of a previously established sociology. The emergence of colonialism, of the Congo and of its populations in Belgian academia was belated and controversial. It opened up a vast and politically charged new repository for very ambitious European theories under the banner of sociology. These theories were generally concerned with a universal theory of social institutions and social relationships. They focused on the rapid changes in the West. They owed their existence in particular to the power and urgency with which the need for them was expressed and to the conviction that they were possible!

This was even more the case in colonial matters. The limitations of the law, philosophy and history seemed even more obvious. The performative effects of the proclamation and positivist faith had an even greater impact. A modern science, sociology, was to go hand in hand with a colonialism which was designed to be modern. The ethnological materials and debates provided it with a wonderful opportunity to exist at a methodological and academic level while proclaiming its ability to establish colonial government.

Until at least 1945-50, the colonial sociology project and its unwavering faith in positivist science unquestionably played a significant part in reinforcing the colonial illusion of obtaining in-depth knowledge on which to base indigenous policy.

The first major project of the first Belgian Society for Sociology (led by Catholics) was a general ethnology project of the Congo! His theoretical conceptions dominated the ethnology dominated official colonial ethnology and sociology for about 40 years (de Bie 1988; Vanderstraeten \&Louckx 2018). Liberals frequently challenged the assumptions and uses of this project with strength and commitment. Some missionaries in the Congo also explored other directions. However, links between colonial ideology and colonial sociology remained very close during this period. In-the-field colonial 
sociology (including ethnology) mainly involved non-professionals until 1950. In Belgium, professors of colonial sociology held chairs of "general sociology" or were non-sociologist colonials.

The European (inter-colonial and even Western) dimension of this knowledge was essential for bolstering the legitimacy of the Independent State of the Congo, and then colonial Belgium. The International Colonial Institute (ICI), which was in fact very Belgian, performed this role successfully from 1894 onwards. After geography and (inevitably) law, ethnology and linguistics illustrated the "Belgicization" of the Congolese human sciences encyclopedia. It was Belgians who completed the ethnological maps and bibliographies of Central Africa. ${ }^{13}$

An instrumental frame of reference remained explicitly omnipresent: the ambition to govern the colony and its population. Some 'sociologists' had substantial doubts about the management of the colony and the civilization ambition. On the basis of field expertise, they issued warnings about the inconsistencies in colonial policies and the destructive influence of colonization on Congolese social and cultural institutions (Hunt 1999). Some also called for greater awareness of the complexity and historicity of African institutions. However, neither the ethnological work of the Catholic missionaries nor the more critical views of a few liberally minded scholars, administrators and magistrates were able to decisively challenge Belgian colonial doctrine and oppose the underlying racial concepts.

The assumed distinction between "civilized" and "uncivilized" (or "primitive") people, along with the widespread use of the notion of race, stood in the way of comparative or generalized studies of European and African societies (Bancel et al. 2014). The boundary drawn between sociology and colonial sociology remained highly impermeable. It was taken for granted that the findings of colonial sociology could not have a direct influence on the sociological study of Western societies. It dealt with the colonial crises and repeated clashes that arose in Africa. Only in exceptional cases could it transcend the concepts it had helped to produce and legitimize: race, ethnicity, the primitive nature of societies, tradition and the disturbing denial of tradition through the figure of the "évolué" (advanced Native).

Overall, colonial sociology in Belgium was unable to develop independently of Belgium's colonization interests before 1945-1950.The limitations of colonial sociology and the impotence of colonial academia became clearer after the end of the Second World War, when ideas about "colonization for development" started to point in other directions. Scholars sought after new scientific competences and new scientific perspectives, however no sociology of colonization processes developed. Not surprisingly, decolonization put an end to all ambitions of colonial sociology.

In the field called for by colonial sociology, ethnological and ethno-historical heritage is least anachronistic. It is sometimes useful for the few researchers, African or not, who survey this subcontinent today. But in the eyes of a sociologist of knowledge, the archives of colonial sociology provide unquestionably a shortcut right to the heart of the colonial incubator of cultural domination. A blurry discipline like sociology produced completely new subject matter and an extensive bibliography. It was blind to its own historical conditions and purposes. It was not uncontested, but it was always destined to become the

\footnotetext{
${ }^{13}$ The largest museum about Central Africa, the new Africa Museum is still located. ...on the outskirts of Brussels.
} 
science of an ultimately modern colonization, based on universal scientific knowledge. What an incredible web of paradoxes, passions and blindness!

There are unquestionably many links between colonial social sciences, colonial ideology and the training of colonial personnel. Sociology, as well as all the colonial sciences, accepted the framework of colonialism, while colonial ideology used scientific discourse and scientism as a way of achieving its ends. But the specific and lasting impact of the colonial sciences, and colonial sociology in particular, on the colonial administration or the Congolese people is difficult to determine. Most precepts and/or policies were only partially and unevenly implemented. There was often a huge gulf between academic speech and field action. Despite the various forms of collaboration between the political, economic, religious and scientific actors, the idea of a colonial administration with totalitarian and science-based panoptic control over the Congo and its population is probably a ... sociological myth.

\section{Compliance with ethical standards}

Conflicts of interest On behalf of all authors, the corresponding author declares that there is no conflict of interest.

Open Access This article is licensed under a Creative Commons Attribution 4.0 International License, which permits use, sharing, adaptation, distribution and reproduction in any medium or format, as long as you give appropriate credit to the original author(s) and the source, provide a link to the Creative Commons licence, and indicate if changes were made. The images or other third party material in this article are included in the article's Creative Commons licence, unless indicated otherwise in a credit line to the material. If material is not included in the article's Creative Commons licence and your intended use is not permitted by statutory regulation or exceeds the permitted use, you will need to obtain permission directly from the copyright holder. To view a copy of this licence, visit http://creativecommons.org/licenses/by/4.0/.

\section{References}

Ballegeer, L. (1946). Pour une politique congolaise. Bulletin du Centre d'Étude des Problèmes Sociaux Indigènes, 4, 3-12.

Bancel, N., David, T., \& Thomas, D. (2014). The Invention of Race: Scientific and Popular Representations. London: Routledge.

Bederman, S. H. (1989). The 1876 Brussels Geographical Conference and the charade of European cooperation in African exploration. Terrae Incognitae, 21(1), 63-73.

Benoit, J. (1959). La population africaine à Elisabethville à la fin de 1957. Elisabethville: CEPSI.

Bevernage, B. (2018). The making of the Congo question: Truth-telling, denial and 'colonial science' in King Leopold's commission of inquiry on the rubber atrocities in the Congo Free State (1904-1905). Rethinking History, 22(2), 203-238.

Bontinck, F. (1985). Aux origines de la philosophie bantoue. La correspondance Tempels-Hulstaert (19441948). Limete, Kinshasa: Faculté de Theologie Catholique.

Bouvier, P. (2015). Le sociologue Arthur Doucy. Anamnèse, 10, 198-205.

Brausch, G. (1961). Belgian Administration in the Congo. London: Oxford University Press.

Caprasse, P. (1959). Leaders africains en milieu urbain. Elisabethville: CEPSI.

Cattier, F. (1906). Etude sur la situation de l'Etat indépendant du Congo. Bruxelles: Larcier.

Clay, D. (2016). Transatlantic dimensions of the Congo Reform Movement, 1904-1908. English Studies in Africa, 59(1), 18-28.

Clémens, R. (1959). Les fondements sociaux de l'action sociale en Afrique belge. Bulletin du Centre d'Étude des Problèmes Sociaux Indigènes, 47, 15-25. 
Cohn, B. S. (1996). Colonialism and Its Forms of Knowledge: The British in India. Princeton: Princeton University Press.

Cooper, F., \& Randall, P. (1997). International Development and the Social Sciences: Essays on the History and Politics of Knowledge. Berkeley: University of California Press.

Cooper, F., \& Stoler, A. L. (1997). Tensions of Empire: Colonial Culture in a Bourgeois World. Berkeley: University of California Press.

Couttenier, M. (2005). Congo tentoongesteld: Een geschiedenis van de Belgische antropologie en het museum van Tervuren (1882-1925). Louvain: ACCO.

Crombois, J.-F. (1998). Le Congo et l'ethnographie: Colonialisme, sociologie et ethnologie en Belgique avant 1914. Civilisations, 45(1/2), 55-84.

Davidson, B. (1955). The African Awakening. London: Cape.

de Bie, P. (1988). Naissance et premiers développements de la sociologie en Belgique. Louvain-la-Neuve: CIACO/ARTEL.

de Calonne Beaufaict, A. (1912). La pénétration de la civilisation au Congo belge. Les bases d'une politique coloniale. Bulletin de la Société Belge d'Études Coloniales, 7/8.

De Jonghe, É. (1908). L'activité ethnologique des Belges au Congo. Bulletin de La Société Belge d'Études Coloniales, 15(4), 283-308.

De Jonghe, É. (1920). L'ethnologie, son objet et sa méthode. Congo, 2, 272-284.

de Villers, G. (2011). Benoît Verhaegen. Bulletin des Séances de l'Académie Royale des Sciences d'OutreMer, 57(1), 75-89.

Demunter, P. (1975). Luttes politiques au Zaïre. Le processus de politisation des masses rurales du bas-Zaïre. Paris: Anthropos.

Depaepe, M., \& Van Rompaey, L. (1995). In het teken van de bevoogding: De educatieve actie in BelgischCongo 1908-1960. Leuven: Garant.

Doucy, A. (1957). Sociologie et réformes de structures au Congo belge. Revue de l'Université de Bruxelles, 9(2-3), 212-229.

Englebert, P. (2009). Africa: Unity, Sovereignty and Sorrow. Boulder: Lynne Rienner.

Forde, D. (1956). Social Implications of Industrialization and Urbanization in Africa, South of the Sahara. London: International African Institute, UNESCO.

Fox, R. C. (1994). In the Belgian Château : the spirit and culture of an European society in an age of change. Dee Edit: Ivan R.

Habig, J.-M. (1948). Initiation à l'Afrique. Bruxelles: Éditions universelles.

Heilbron, J., Magnusson, L., \& Wittrock, B. (Eds.). (1998). The rise of the social sciences and the formation of modernity. Dordrecht: Springer.

Hochschild, A. (1999). King Leopold's Ghost: A Story of Greed, Terror, and Heroism in Colonial Africa. Boston: Houghton Mifflin Harcourt.

Hund, W. D., \& Lentin, A. (Eds.). (2014). Racism and Sociology. Münster: LIT Verlag.

Hunt, N. R. (1999). A Colonial Lexicon: Of Birth Ritual, Medicalization, and Mobility in the Congo. Durham: Duke University Press.

Hunt, N. (2016). A Nervous State. Violence, Remedies, and Reverie in Colonial Congo. Durham: Duke University Press.

KAOW-ARSOM. (1962). Apport scientifique de la Belgique au développement de l'Afrique centrale: Livre blanc. Vol. 1, Introduction: Sciences morales et politiques. Bruxelles: KAOW-ARSOM.

Kennes, E. (2014). Fin du cycle post-colonial au Katanga, RD Congo Rébellions, sécession et leurs mémoires dans la dynamique des articulations entre État central et autonomie régionale. Paris: Univ. européennes.

Lehmann, J. M. (1995). The question of caste in modern society: Durkheim's contradictory theories of race, class, and sex. American Sociological Review, 60(4), 566-585.

Leimdorfer, F. (1992). Discours académique et colonisation. Thèmes de recherches sur l'Algérie pendant la période coloniale. Paris: Publisud.

Lösing, F. (2014). From the Congo to Chicago. Robert E. Park's romance with racism. In A. Lentin \& W. D. Hund (Eds.), Racism and Sociology (pp. 107-122). Münster: Lit Verlag.

Lyman, S. M. (1990). Robert E. Park reconsidered: The early writings. The American Sociologist, 21(4), $342-351$.

Lyman, S. M. (1991). Robert E. Park's Congo papers: A gothic perspective on capitalism and imperialism. International Journal of Politics, Culture, and Society, 4(4), 501-516.

Madan, G. R. (1979). Western Sociologists on Indian Society: Marx, Spencer, Weber, Durkheim, Pareto. London, Boston: Routledge \& Kegan Paul.

Maquet, J.-J. (1949). The modern evolution of African populations in Belgian Congo. Africa, 19(4), $265-272$.

Marchal, J. (1996). E.D. Morel contre Léopold II: l'Histoire du Congo. Volume 1. Paris: 1'Harmattan.

Minon, P. (1960). Katuba. Étude quantitative d'une communauté urbaine africaine. Elisabethville: CEPSI. 
Ndaywel è Nziem, I. (2006). L'historiographie congolaise. Un essai de bilan. Civilisations. Revue Internationale d'Anthropologie et de Sciences Humaines, 54, 237-254.

Poncelet, M. (2008). L'invention des sciences coloniales belges. Paris: Karthala.

Poncelet, M. (2015). Fin de colonie. Bricolages du développement. René Clémens et la mobilisation des universitaires liégeois au Katanga dans les années 1955-1960. Anamnèse, 10, 205-223.

Poncelet, M., André, G., \& de Herdt, T. (2010). La survie de l'école primaire congolaise (RDC): héritage colonial, hybridité et résilience. Autrepart, 54(2), 23-41.

Richelle, M. (1960). Aspects psychologiques de l'acculturation. Recherche sur les motivations de la stabilisation urbaine au Katanga. Liège: FULREAC.

Rubbers, B., \& Poncelet, M. (2015). Sociologie coloniale au Congo belge. Les études sur le Katanga industriel et urbain à la veille de l'Indépendance. Genèses, 99(2), 93-112.

Salkin, P. (1920). Études africaines. Bruxelles, Paris: Éditions Larcier, Chalamael.

Salkin, P. (1926). Le problème de l'évolution noire. L'Afrique centrale dans cent ans. Paris, Bruxelles: Éditions Payot, Archives et musée de la littérature.

Schatzberg, M. (2012). The structural roots of the DRCs current disasters: Deep dilemmas. African Studies Review, 55(1), 117-121.

Sibeud, E. (2002). Une science impériale pour l'Afrique. La construction des savoirs africanistes en France 1878-1930. Paris: Editions de l'EHESS.

Simar, T. (1922). Etude critique de la formation de la doctrine des races au XVIIIe siècle et son expansion au XIXe siècle. Bruxelles: Hayez.

Steinmetz, G. (Ed.). (2013). Sociology \& Empire: The Imperial Entanglements of a Discipline. Durham: Duke University Press.

Stoler, A. L. (2013). Repenser le colonialisme. Paris: Payot.

Tempels, P. (1959). Bantu philosophy. Paris: Présence africaine.

Van der Kerken, G. (1920). Les sociétés bantoues du Congo belge et les problèmes de la politique indigène: étude de la politique coloniale adoptée au Congo belge et de ses problèmes dans l'ordre sociologique, politique et économique. Bruxelles: Éd. Émile Bruylant.

Van der Kerken, G. (1944). L'ethnie Mongo. Histoire, groupements, sous-groupements, origine, représentation, visions, explications du monde; sociologie, économie, ergologie, langues et arts des peuples Mongo. Bruxelles: G. Van Campenhout.

Van Reybrouck, D. (2014). Congo: The Epic History of a People. London: Fourth Estate.

Van Wing, J. (1921). Etudes bakongo: histoire et sociologie. Bruxelles: Goemaere.

Van Wing, J. (1951). Le Congo déraille. Gemboux: Duculot.

Vandersmissen, J. (2011). The king's most eloquent campaigner... Emile de Laveleye, Leopold II and the creation of the Congo Free State. Journal of Belgian History, 41(1-2), 7-57.

Vanderstraeten, R., \& Louckx, K. (2018). Sociology in Belgium: A Sociological History. Basingstoke: Palgrave Macmillan.

Vandervelde, E. (1911). La Belgique et le Congo. Le passé, le présent et le futur. Paris: Alcan.

Vansina, J. (1994). Living with Africa. Madison: University of Wisconsin Press.

Vanthemsche, G. (2012). Belgium and the Congo 1885-1980. New York: Cambridge University Press.

Vermeersch, A. (1906). La question congolaise. Bruxelles: C. Bulens.

Viaene, V. (2008). King Leopold's imperialism and the origins of the Belgian Colonial Party, 1860-1905. The Journal of Modern History, 80(4), 741-790.

Vinck, H. (2000). Dimensions et inspiration de l'œuvre de Gustaaf Hulstaert. Revue africaine des Sciences de la Mission/African Review of Mission Studies, 12, 208-236.

Wallerstein, I. (1963). Review of 'Les Citadins Katangais et leurs Jardins: Aspects psycho-sociaux de la Vie en Milieu Africain Urbain; Une Famille de Citadins du Katanga by Robert Dethier'. American Anthropologist, 65(2), $474-474$.

Wauters, A.-J., \& Buyl, A. (1895). Bibliographie du Congo, 1880-1895: Catalogue méthodique de 3,800 ouvrages, brochures notices et cartes relatifs à l'histoire, à la géographie et à la colonisation du Congo. Bruxelles: Administration du Mouvement Géographique.

Yates, B. A. (1976). The triumph and failure of mission vocational education in Zaïre 1879-1908. Comparative Education Review, 20(2), 193-208.

Young, C. (1965). Politics in Congo: Decolonization and Independence. Princeton: Princeton University Press.

Zimmerman, A. (2010). Anthropology and Antihumanism in Imperial Germany. Chicago: The University of Chicago Press.

Publisher's Note Springer Nature remains neutral with regard to jurisdictional claims in published maps and institutional affiliations. 